\title{
Noise Pollution at Health Care Centers in Mymensingh City of Bangladesh
}

\author{
M. A. Islam*, M. S. Rahman, B. Roy and M. A. M. Hossen
}

Department of Environmental Science,

Bangladesh Agricultural University, Mymensingh-2202, Bangladesh

*Corresponding author: islamaminulak@gmail.com

\begin{abstract}
The study was conducted at the health care centers in Mymensingh city of Bangladesh during the period from March 2015 to November 2015 to find out the level of noise pollution and its severity to the associated health effects. In the study, time-weighted average noise levels were measured at indoor and outdoor of three hospitals namely Mymensingh Medical College and Hospital, Rajdhani Hospital (Pvt.) Limited and Shawdesh Hospital (Pvt.) Limited and two clinics such as Popular Diagnostic Centre Ltd, Safeway Diagnostic Centre Ltd. of Mymensingh city. The highest noise level was found in Mymensingh Medical College and Hospital and the lowest level was found in Shawdesh Hospital (Pvt.) Limited, Sarda Gosh Road. All of these noise levels were exceeded the acceptable limit of $45 \mathrm{~dB}$ set by the Department of Environment (DoE), Government of Bangladesh. Simultaneously a survey study was conducted with doctors, students, nurse/staff and patients. Most of the common problems occurred from noise pollution were identified as conversation, headache, hearing problems, and increased heartbeat. To resolve the problem $28 \%$ of the respondents suggested for sound harriers, $25 \%$ suggested for awareness of doctors, $22 \%$ suggested for awareness of visitors, $13 \%$ suggested for controlling visitors and $4 \%$ suggested for banning of hydraulic horn. However, the role of NGOs, researchers and professionals, media and concerned individuals is significant in minimizing the environmental hazards of noise pollution.
\end{abstract}

Key words: Clinics, Hospitals, Noise level, Noise pollution problems

\section{Introduction}

In Bangladesh noise pollution also termed as sound pollution is a major health hazard. In fact, due to noise pollution millions of people in Bangladesh are exposed to a number of health risks from deafness to heart attack. On city streets noise pollution can be caused by hydraulic horns of vehicles, microphones and cassette players. Noise pollution exists in hospitals all over the world, is a common stressor and is recognized as not just as a nuisance but a serious health hazard. Various studies have measured hospital noise and linked to negative patients' quality care (Juang et al., 2010; Pope, 2010; Moshi et al., 2011). Evidence has also been accumulated that noise is a risk factor in sleep disturbance (Gabor et al., 2003; Xie et al., 2009), cardiovascular dysfunction, speech interference and mental health distortion, including hearing impairment and balance disorder (Satterfield, 2001; Ising and Kruppa, 2004). The effect may not only affect the patient's wellbeing and comfort, but may also cause stress for the staff, decreasing work performance and increasing anxiety. Noise pollution has been found unacceptably high in operating theatres, intensive care units, hemodialysis centers, and also at the patient's room. The source of noise pollution include doors slamming, trolleys rolling in corridors, alarms and moving parts of medical equipment are all important as are the frequently loud conversations among, staff members or visitors in hospitals (Safarpour et al., 2010). Along with the increasing degree of air and water pollution, noise pollution is also emerging as a new threat to the inhabitants of Mymensingh city-one of the large cities in Bangladesh. General hospitals and clinics of the city are located along the roadsides and around the busy places of the city. For this reason, the level of noise pollution at the major hospitals and clinics in Mymensingh City Corporation is very closely related with urbanization and motorization levels. Here, in the present study, noise levels at various places of indoor, outdoor and emergency departments at the selected hospitals and clinics of Mymensingh City Corporation area were measured and compared with the World health organization regulation to attain the following objectives: i) to determine the level of noise pollution at major health care centers at Mymensingh City Corporation, ii) to determine the variation of noise levels throughout a day, iii) to identify the major sources of noise pollution, and iv) to assess the health effects of noise pollution.

\section{Materials and Methods}

\section{Study area}

The study site was Ward no 04 and 06 under Mymensingh Municipal Area $\left(24^{\circ} 45^{\prime} 00^{\prime \prime} \mathrm{N}\right.$ $90^{\circ} 25^{\prime} 00^{\prime \prime} \mathrm{E} / 24.7500^{\circ} \mathrm{N} 90.4167^{\circ} \mathrm{E}$ ), north side of Dhaka (capital of Bangladesh). It's one of the largest municipal area in Bangladesh with an area of $21.73 \mathrm{~km}^{2}$ that bared a huge Population number 225811 where male $51.91 \%$, female $48.09 \%$ and density of population per sq km 10392 (BBS, 2001).

1. Mymensingh Medical College and Hospital

2. Rajdhani Hospital (Pvt.) Limited, Bhatikasor

3. Shawdesh Hospital (Pvt.) Limited, Sarda Gosh Road

4. Popular Diagnostic Centre Ltd, Chorpara

5. Safeway Diagnostic Centre Ltd. 

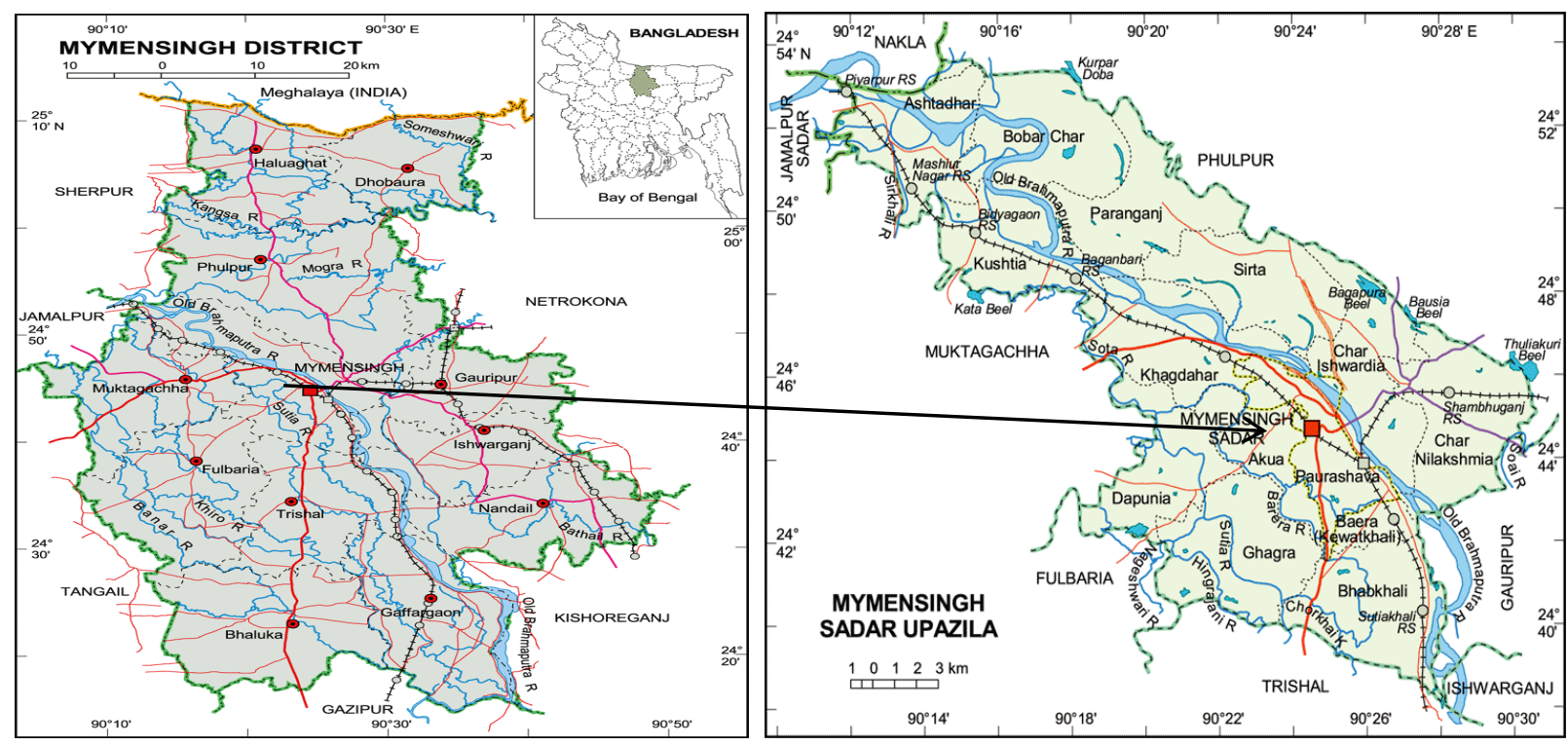

Fig. 1. Map of Mymensingh City Corporation indicating study locations of clinics and hospitals (Source: Banglapedia, 2004)

Three hospitals and two clinics located at Mymensingh City Corporation area were selected according to the objectives of the study, which included: Mymensingh Medical College and Hospital, Rajdhani Hospital (Pvt.) Limited, Shawdesh Hospital (Pvt.) Limited, Popular Diagnostic Centre Ltd, Safeway Diagnostic Centre Ltd (Fig. 1). Selection process was based on ease of collection of required data and proximate information and noise polluting sources.

\section{Measurement of noise level}

The basic instrument for measuring sound is the sound level meter. In this study, Multi-Function Environmental Meter was used for data collection. Measurement range is: 1 ) $\mathrm{Lo}=35-100 \mathrm{~dB}$; ii) $\mathrm{Hi}=65$ $130 \mathrm{~dB}$ (Frequency Weighting: A, C). Sound level meters are usually equipped with weighting circuits which filter out selected frequencies. It has been found that the A-scale on a sound level meter best approximates the frequency response of the human ear. The most common measure of sound level is sound intensity and pressure. Sound intensity is the average rate of sound energy transmitted through a unit is perpendicular to the direction of the sound propagation, typically measure in Pico-watts per square meter. Sound pressure levels measured on the scale of a sound meter are abbreviated $\mathrm{dB}$.

\section{Data collection}

Noise levels at different hospitals and clinics of Mymensingh City Corporation area were conducted for a period of one year from March 2015 to November 2015. The measurement of noise levels were carried out between the periods of 10:00 AM to 2:00 PM and 5:00 to 7:00 PM with the help of a sound level meter both in the indoor and outdoor spaces of the selected three hospitals and two clinics. Reading was taken in each hourly interval for a period of one minute both on working days and weekends. In order to assess health effects of noise pollution and identify sources of it, a questionnaire survey was conducted. Randomly selected samples were divided into four groups i.e. medical students, patients, doctors and nurse/staff. From each study location, five doctors, ten nurses/staffs, ten patients and ten students were interviewed face to face for accomplishing the survey. In this study, secondary data or relevant information were collected from various noise pollution related literature, books, journals and websites, etc.

\section{Data processing and analysis}

The collected data were analyzed with the help of Microsoft Excel and the results obtained were presented in the tables to explain the condition of noise level at hospitals and clinics of Mymensingh City.

\section{Results and Discussion}

The monthly variations in noise levels at the hospitals in Mymensingh city is shown in Table 1. The highest and lowest mean noise levels in Mymensingh Medical College and Hospital were observed $116.6 \mathrm{~dB}$ in August and $91.7 \mathrm{~dB}$ in September. The recorded highest and lowest mean noise levels of Rajdhani Hospital (Pvt.) Limited, Shawdesh Hospital (Pvt.) Limited, Popular Diagnostic Centre Ltd, Safeway Diagnostic Centre Ltd, Chorpara were 101.1 dB in March, 101.3 $\mathrm{dB}$ in May, 107.9 dB in July and $100.5 \mathrm{~dB}$ in March respectively and $87.6 \mathrm{~dB}$ in August, $81.7 \mathrm{~dB}$ in July, $92.3 \mathrm{~dB}$ in May and $86.5 \mathrm{~dB}$ in May respectively. The highest noise level was found in Mymensingh Medical College and Hospital and the lowest level was found in Shawdesh Hospital (Pvt.) Limited, Sarda Gosh Road. All of these noise levels were exceeded the acceptable limit of $45 \mathrm{~dB}$ set by the Department of Environment (DoE), Government of Bangladesh (ECR, 1997). The major sources of noise pollution at the health care centers are shown in table 2. Most of the respondents directly suggested the major cause of noise pollution is crowded by visitors.

\section{Health effects of noise pollution}


The respondents themselves personally suffered from many problems caused by noise pollution. The most common problems that they were suffering included headache, hearing problem, problem in conversation, absent-mind, palpitation and drowsiness (Table 3). Possible remedial measures for noise pollution: In order to reduce noise pollution, $50 \%$ medical students suggested for increased awareness of visitors, $22 \%$ suggested for banning of hydraulic horns, $11 \%$ suggested for awareness of doctors. 3\% suggested for awareness of authority and $14 \%$ did not give any suggestion. About $22 \%$ patients suggested for awareness of visitors. 4\% suggested for banning of hydraulic horn, $25 \%$ suggested for awareness of doctors, $28 \%$ suggested for created sound barriers, $13 \%$ suggested for controlling visitors and $8 \%$ did not give any suggestion.

Table 1. Noise level in front of some selected hospitals and clinics in Mymensingh City (Average peak hour's data only: 10:00 AM to 2:00 PM and 5:00 to 7:00 PM).

\begin{tabular}{|c|c|c|c|c|c|c|c|c|c|c|}
\hline $\begin{array}{l}\text { Sl. } \\
\text { No. }\end{array}$ & Locations & $\begin{array}{c}\text { Mean } \\
\text { Noise } \\
\text { level } \\
(\mathrm{dB}) \\
\text { in } \\
\text { March } \\
\end{array}$ & $\begin{array}{c}\text { Mean } \\
\text { Noise } \\
\text { level } \\
\text { (dB) } \\
\text { in } \\
\text { April } \\
\end{array}$ & $\begin{array}{l}\text { Mean } \\
\text { Noise } \\
\text { level } \\
(\mathrm{dB}) \\
\text { in May }\end{array}$ & $\begin{array}{l}\text { Mean } \\
\text { Noise } \\
\text { level } \\
\text { (dB) } \\
\text { in June }\end{array}$ & $\begin{array}{l}\text { Mean } \\
\text { Noise } \\
\text { level } \\
\text { (dB) } \\
\text { in July }\end{array}$ & $\begin{array}{l}\text { Mean } \\
\text { Noise } \\
\text { level } \\
\text { (dB) } \\
\text { in } \\
\text { August }\end{array}$ & $\begin{array}{l}\text { Mean } \\
\text { Noise } \\
\text { level } \\
\text { (dB) } \\
\text { in Sept. }\end{array}$ & $\begin{array}{l}\text { Mean } \\
\text { Noise } \\
\text { level } \\
\text { (dB) } \\
\text { in Oct. }\end{array}$ & $\begin{array}{l}\text { Mean Noise } \\
\text { level } \\
(\mathrm{dB}) \\
\quad \text { in Nov. }\end{array}$ \\
\hline 1 & $\begin{array}{l}\text { Mymensingh } \\
\text { Medical } \\
\text { College and } \\
\text { Hospital }\end{array}$ & 103.2 & 107.8 & 98.7 & 95.3 & 102.1 & 116.6 & 103.3 & 91.7 & 106.5 \\
\hline 2 & $\begin{array}{c}\text { Rajdhani } \\
\text { Hospital (Pvt.) } \\
\text { Limited, } \\
\text { Bhatikasor }\end{array}$ & 101.1 & 95.3 & 89.6 & 91.4 & 100.4 & 87.6 & 90.7 & 103.3 & 88.6 \\
\hline 3 & $\begin{array}{c}\text { Shawdesh } \\
\text { Hospital (Pvt.) } \\
\text { Limited, } \\
\text { Sarda Gosh } \\
\text { Road }\end{array}$ & 99.9 & 87.3 & 101.3 & 90.7 & 81.7 & 99.4 & 99.1 & 95.7 & 90.5 \\
\hline 4 & $\begin{array}{c}\text { Popular } \\
\text { Diagnostic } \\
\text { Centre Ltd, } \\
\text { Chorpara }\end{array}$ & 100.2 & 100.7 & 92.3 & 99.6 & 107.9 & 99.3 & 98.1 & 103.2 & 101.1 \\
\hline 5 & $\begin{array}{c}\text { Safeway } \\
\text { Diagnostic } \\
\text { Centre Ltd, } \\
\text { Chorpara }\end{array}$ & 100.5 & 87.3 & 86.5 & 87.1 & 95.4 & 99.3 & 98.4 & 91.3 & 92.6 \\
\hline
\end{tabular}

Table 2. Sources of noise at hospital and clinics at Mymensingh city according to the respondents

\begin{tabular}{|l|c|c|c|c|}
\hline Noise Sources & Doctors (\%) & $\begin{array}{c}\text { Medical Students } \\
(\%)\end{array}$ & Nurses/Stuffs (\%) & Patients (\%) \\
\hline Crowd (Visitors) & 60 & 48 & 67 & 67 \\
\hline Vehicles & 20 & 21 & 7 & 9 \\
\hline Instruments & 3 & 2 & - & - \\
\hline Construction & 6 & 13 & 3 & - \\
\hline Sound of TV & - & - & 7 & 5 \\
\hline No Comments & 11 & 16 & & 9 \\
\hline
\end{tabular}


Table 3. Comments of respondents in case of health effects of noise pollution

\begin{tabular}{|l|c|c|c|c|}
\hline Events & Doctors (\%) & $\begin{array}{c}\text { Medical Students } \\
(\%)\end{array}$ & $\begin{array}{c}\text { Nurses Stuffs } \\
(00)\end{array}$ & Patients (\%) \\
\hline Headache & 25 & 40 & 31 & 34 \\
\hline Hearing problem & 40 & 22 & - & - \\
\hline Conversation & 20 & - & - & 13 \\
\hline Absent-minded & 7 & - & 12 & 7 \\
\hline Palpitation & - & 5 & - & 19 \\
\hline Drowsiness & - & 73 & & 15 \\
\hline No problem & 8 & & & \\
\hline
\end{tabular}

\section{Conclusions}

Noise pollution is becoming a major public health concern with all of its potential biological and social effects. Here the study recorded noise levels exceeded the DoE standard of $45 \mathrm{~dB}$ in all three hospitals and two clinics. The study also identified that the main sources of noise pollution at hospitals were crowd traffic volume and hydraulic horns, sound of TV, construction activities etc. However, noise pollution at hospitals is a serious but neglected issue in Mymensingh City and throughout the country. In Bangladesh, little has been done so far to reduce noise pollution. The authority concerned must create awareness among the people so that in the long run people can eradicate noise pollution from the country once for all. Hence, it is now an urgent need and a high time for the role of NGOs, the media, researchers, professionals, concerned individuals and the government of Bangladesh to work together to reduce the problem and increase the quality of health care environment.

\section{Acknowledgements}

The authors sincerely acknowledged the Mymensingh City Corporation, Medical college and clinics authorities for their kind cooperation and consideration to carry out the research smoothly.

\section{References}

Banglapedia. 2004. National Encyclopedia of

Bangladesh, Asiatic Society of Bangladesh, Dhaka, Bangladesh.

BBS (Bangladesh Bureau of Statistics). 2001.

ECR (Environmental Conservation Rule). 1997. Bangladesh Gazette, Ministry of Environmental and Forest (MoEF), Government of Bangladesh (GoB).
Gabor, J. Y.; Cooper, A. 13.; Crombach, S. A.; Lee, B.; Kadikar, N.; Bettger, F. E. and Hanly, P. J.2003. Contribution of the intensive care unit environment to sleep disruption in mechanically ventilated patients and healthy subjects. Ameri. Respira. Critical Care Medicine, 167:708-715.

Ising, H. and Kruppa, B. 2004. Health Effects caused by noise: Evidence in the Literature from the Past 25 Years. Noise Health, 22:5-13.

Islam, M. S.; Shil, S. C.; Akter, A. Bakali, B. and S. Roy. 2013. Investigation of noise level and its effect on surrounding environment in municipality of Tangail district, Bangladesh.

Juang, D. F.; Lee, C. H.; Yang, T. and N. C. Change. 2010. Noise pollution and its effects on medical care workers and patients in hospitals. Int. J. Environ. Sci. Techno., 7(4):705-716.

Moshi, A. A.; Philimoni, M. K. and Mkoma, S. L. 2011. Noise Pollution on Wards in Iringa Regional Hospital, Tanzania. Worl. Appl. J. Sci., 11(5):599603.

Pope, D. 2010. Decibel levels and noise generators on four medicalisurgical nursing units. J. Clinic. Nursing, 19(17-18):2463-2470.

Safarpour, A. R.; Nasabi, N. A.; Mehrabi, M.; Hojatymanesh, M. and Tabatabai, S. H. R. 2010. Comparison of Physical Status of Admission Wards of Shiraz Training Hospitals with Standards in 2008. World Appl. Sci. J., 8(10):1205-1210.

Satterfield, K. 2001. Balance disorders and patients with N1HL in on ear. Academy of Otolaryngology Head and Neck Surgery, 703:1-3.

Xie, H.; Kang, H. and Mills, G. H. 2009. Clinical review: The impact of noise on patients' sleep and the effectiveness of noise reduction strategies in intensive care units. Critical Care, 13(2) 208-215. 